\title{
Elastic and Strength Properties of OSB Layers
}

\section{Elastičnost i čvrstoća slojeva OSB ploča}

\author{
Original scientific paper • Izvorni znanstveni rad \\ Received-prispjelo: 26. 3. 2015. \\ Accepted-prihvaćeno: 15. 11. 2016. \\ UDK: $630 * 863.2 ; 630 * 812.7$ \\ doi:10.5552/drind.2017.1521
}

\begin{abstract}
Experiments were conducted to determine the elastic and strength properties of the face and core layers of a commercial OSB/3 (oriented strand board) panel, $18 \mathrm{~mm}$ thick. Five elastic constants for each layer, as well tensile strength in three directions $\left(0^{\circ}, 45^{\circ}\right.$ and $90^{\circ}$ with respect to the major OSB axis) were obtained in tension testing. Deformations of the samples were measured with the aid of resistance strain gauges. All the Young's moduli as well as the shear modulus of the face layer were distinctly higher than those of the core layer $(2.18-2.23$ and 2 times, respectively). The density of the face layer turned out to be $40 \%$ higher than that of the core one. All the obtained results confirm that the face and core layers of the OSB/3 panel differ considerable in respect of density, elastic and strength properties but they have orthotropic properties.
\end{abstract}

Key words: elastic and strength properties, oriented strand board (OSB), orthotropy, Young's modulus, shear modulus

SAŽETAK - Istraživanja su provedena kako bi se odredila elastična svojstva i čvrstoća vanjskih $i$ unutarnjih slojeva komercijalne OSB/3 ploče debljine $18 \mathrm{~mm}$. Primjenom vlačnog testa dobivene su vrijednosti pet konstanti elastičnosti za svaki sloj, kao i vlačna čvrstoća u tri smjera $\left(0^{\circ}, 45^{\circ}\right.$ i $90^{\circ}$ s obzirom na glavnu os OSB ploče). Deformacije uzoraka mjerene su mjernim instrumentima za otpornost materijala. Sve vrijednosti Youngova modula elastičnosti, kao i vrijednosti modula smicanja vanjskih slojeva, bile su značajno veće od vrijednosti dobivenih za unutarnje slojeve (2,18 - 2,23 puta veće za Youngove module elastičnosti i dvaput za module smicanja). Gustoća vanjskoga sloja bila je 40 \% veća od gustoće unutarnjih slojeva ploče. Svi dobiveni rezultati potvrđuju da se vanjski i unutarnji slojevi OSB/3 ploče značajno razlikuju u smislu gustoće, elastičnih svojstava i čvrstoće, ali pokazuju i ortotropna svojstva ploče.

Ključne riječi: elastična svojstva i čvrstoća, ploče s orijentiranim iverjem (OSB), ortotropna svojstva, Youngov modul, modul smicanja

\section{INTRODUCTION 1. UVOD}

Oriented strand board (OSB) made from hotpressing strand mats, consisting of slender wood strands glued with water-resistant resins (OSB/3 and OSB/4 grades), usually are formed of three layers crossing at right angle. Strands in the upper and lower faces are oriented approximately along the major board axis, but in the core strands they are usually at $90^{\circ}$ to this direction. OSB is often assumed to be an orthotropic material (Canadido et al., 1988; Wang and Chen, 2001; Zhu et al., 2005), but it is rather a threelayer cross laminate (Bodig and Jayne, 1982), and only on condition that the layers are strictly orthotropic and the number of the layers is big enough the laminate may be assumed to be orthotropic, too (Ashkenazi, 1978).

\footnotetext{
${ }^{1}$ The authors are assistant professors at the Poznań University of Life Sciences, Faculty of Wood Technology, Poznań, Poland. ${ }^{2}$ The author is MCs student of Faculty of Wood Technology, Poznań University of Life Sciences, Poznań, Poland.

${ }^{1}$ Autori su docenti Sveučilišta bioloških znanosti u Poznanju, Fakultet drvne tehnologije, Poznanj, Poljska. ${ }^{2}$ Autor je student Fakulteta drvne tehnologije, Sveučilište bioloških znanosti u Poznanju, Poznanj, Poljska.
} 
The moduli of elasticity (MOEs) of the entire OSB panel mentioned in the PN-EN 300, PN-EN 310, PN-EN 12369-1 and PN-EN 789 standards are obtained in bending tests with the load perpendicular to the panel plane. Actually, for the OSB panel treated in bending perpendicularly to the plane as a layered system (Bodig and Jayne, 1982), the moduli of the various layers may be converted to a single modulus for the entire OSB specimen using so-called transformed cross section method. Therefore, OSB as a layered system can be modelled using an equivalent homogenous material for which the moduli of elasticity in directions of major and minor board axes are assumed to be constant throughout the entire cross section of the OSB panel. Obtained in such bending tests, the values of the OSB moduli of elasticity are completely incomparable with those obtained by the tension, compression or bending tests in the plane of the panel (Suzuki, 2000). MOE of the entire OSB sample in bending perpendicular to the panel plane in contrast to the in-plane bending is strongly, nonlinearly, affected not only by the strand orientation but by the face/core ratio, as well (Suzuki, 2000; Chen et al., 2008). Additionally, moduli obtained according to the above mentioned standards are useless for the design of the composite box- or I-beams, where OSB webs of those beams are in two-dimensional stress state (in plane stress), as a consequence of their in-plane bending. Therefore, the OSB moduli of elasticity estimated by the out-of-plane bending tests are only the apparent moduli (Carll and Link, 1988; Thomas, 2003). These effective OSB moduli of elasticity are influenced not only by the shape, size and distribution of strands (Nishimura et al., 2004), but also by the orientation of the strands, particularly in surface layers (Shupe et al., 2001; Wang and Chen, 2001). Therefore, the influence of these and many other factors on the effective MOE of OSB was often investigated but usually on plates manufactured in laboratory. Many theoretical models to investigate the influence of orientation level of strands or also of the vertical density profile and other factors on the effective MOE of OSB plates (Xu, 2000; Painter et al., 2006 a,b) were developed, too. A methodology to explain the fundamental formation of the vertical density profile of OSB plates during the processing period was developed by Winistorfer et al. (2000) and by Wang and Winistorfer (2000). The industrially manufactured OSB have " $U$ " (Böhm et al., 2011) or rather "M" shaped vertical density profile (Painter et al., 2006 a,b) in numerical simulations assumed to be symmetrical about the mid-plane. Therefore, both the surface layers have a higher density than the internal one and consequently the OSB panel achieves higher bending strength and bending MOEs. To determine the variation in strength and elastic properties through the thickness of the OSB panel, Steidl et al. (2003) divided 23/32-inch-thick commercial southern pine OSB panel into 15 layers to obtain thin-layer specimens for tension and compression testing. The layer properties were used to predict the entire panel bending properties (apparent bending MOEs) but the experimental data were not as good as expected.
The objective of this study was to obtain experimentally all the elastic constants of the surface and inner layers of a commercial OSB panel, which are essential for the prediction of the elastic constants of entire OSB plate according to the laminate theory (Bodig and Jayne, 1982). The assumption was made that the OSB panel is a symmetric laminate consisting of three orthotropic layers crossing at right angle. More direct method of strain measurements with the aid of resistance strain gauges was chosen.

\section{MATERIAL AND METHODS 2. MATERIJAL I METODE}

All specimens were cut from one 1250 by 2500 $\mathrm{mm}, 18 \mathrm{~mm}$ thick commercial $\mathrm{OSB} / 3$ panel. The $\mathrm{OSB} / 3$ panel (bearing panel for use in wet conditions, according to the PN-EN 300 standard) was formed of three layers crossing at right angle. The inner layer (core) was bonded with the MDI (methylene-diphenyle-diisocyanate) adhesive, while the outer layers (faces) were bonded with the MUPF (melamine-ureaphenol-formaldehyde) resins. The OSB panel was made of flat, differently wide strands (generally of pine wood - Pinus sylvestris L.), 100 - $120 \mathrm{~mm}$ long and 0.6 $\mathrm{mm}$ thick and manufactured with the use of the ContiRoll press by Kronopol-Żary, Poland. The faces/core weight ratio of the OSB/3 panel was about $50 / 50$, in accordance with the manufacturer's data. The average density of the OSB/3 panel of $593 \mathrm{~kg} / \mathrm{m}^{3}$ was obtained in accordance with the PN-EN 323 standard just before the mechanical investigations at the average moisture content of $7.6 \%$ obtained in accordance with the PNEN 322 standard on the same specimens.

The preparation of the specimens for the experiments of elastic and strength properties consisted of two stages. In the first stage, 72 full-thickness test pieces 510 by $30 \mathrm{~mm}$ were cut from the OSB/3 panel: 25 pieces at $0^{\circ}, 20$ pieces at $90^{\circ}$ and 27 at $45^{\circ}$ with respect to the longer edge (major axis) of the OSB sheet. Five pieces of each orientation type, in total 15 pieces, were randomly selected from the larger group for the experiments of elastic properties. Similarly, another 15 pieces were randomly selected for the experiments of strength properties.

In the second stage, all the selected pieces were sawn into two separate specimens: the inner ones 5.5 $\mathrm{mm}$ thick from a core layer, symmetrical about the OSB mid-plane and the surface ones $3 \mathrm{~mm}$ thick, always from the same, upper face layer. Such thickness of the specimens was chosen because of a lack of the technical data about the thickness of individual layers of $18 \mathrm{~mm}$ thick OSB/3 plates. The thickness of both face layers was estimated to be between 2 and $3.5 \mathrm{~mm}$ (on the basis of our own experiments).

All the 30 specimens of three orientation types and of two separate layers, provided for the experiments of elastic properties, were equipped with two $120 \mathrm{ohm}$ strain gauges of TFs-15/120 or HBM 10/120 LY 11 types situated at right angles to each other on the surface of each specimen in such a way that one of the 
a)

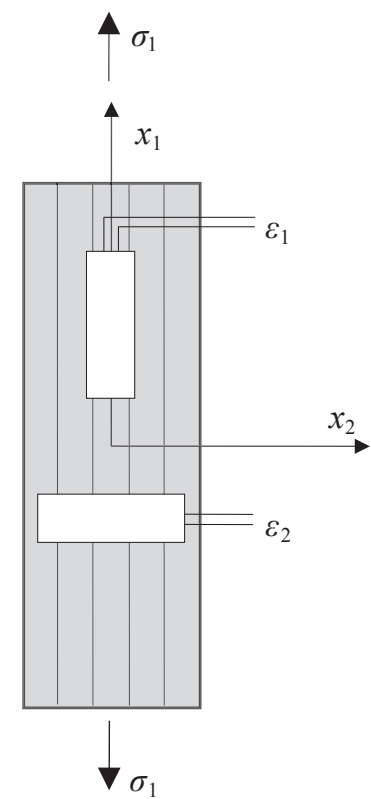

b)

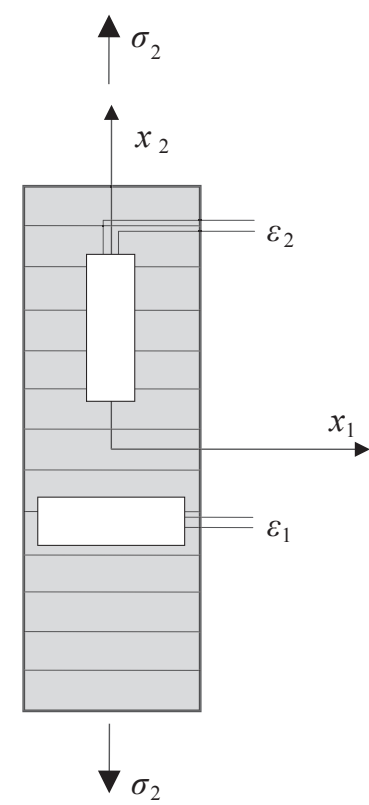

c)

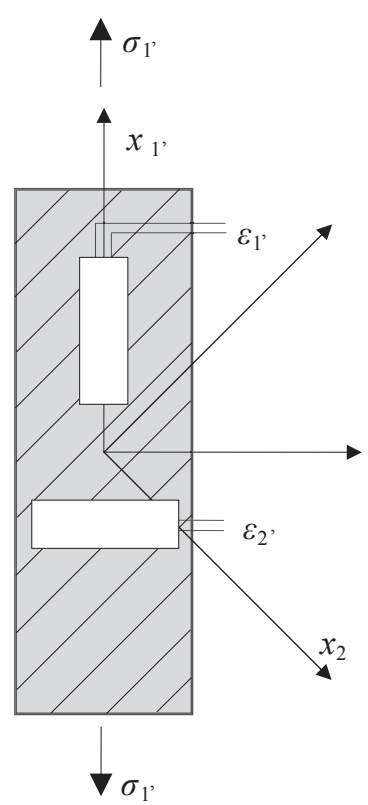

Figure 1 Scheme of loading and strain measurement for the tension tests of face specimens. Specimens orientation: a) at $0^{\circ}$; b) at $90^{\circ}$; c) at $45^{\circ}$ with respect to the major OSB panel axis, $x_{1}$

Slika 1. Shema opterećenja uzoraka i mjerenja naprezanja pri vlačnom testu uzoraka vanjskih slojeva ploče. Orijentacija uzoraka: a) $0^{\circ}$; b) $90^{\circ}$; c) $45^{\circ}$ u odnosu prema smjeru glavne osi OSB ploče $x_{1}$

strain gauges was situated parallel to the longer edge of this specimen (Fig. 1.). The specimens in the form of thin rectangular parallelepipeds were investigated in quasi-static tension tests. The gravity loading was realized by steel disks underslung to the bottom end of the specimen when the top end of the specimen was chucked directly in immovable grips of the FPZ 100/1 testing machine. Only the diagonal specimens (cut at $45^{\circ}$ with respect to the OSB major axis) were fastened with the aid of special grips with a rod inserted into two bore-holes of $9 \mathrm{~mm}$ diameter, $40 \mathrm{~mm}$ from the ends of these specimens to enable shear strains without additional shear stresses. Before the basic tension tests, all the specimens were subjected to a mechanical preconditioning consisting in fivefold loading-unloading cycles (from the preload to the maximum load) to minimize the influence of plastic strains on the results of these experiments.

Three various levels of the maximum load were chosen, taking into consideration the cross-section of each specimen type (face or core), as well as their orientation (at $0^{\circ}, 45^{\circ}$ or $90^{\circ}$ with respect to the OSB panel major axis). These load levels were chosen assuming that the stress level during the tension tests should not exceed $30 \%$ of the tensile strength. Each specimen was subjected to a fivefold load, from the preload up to the maximal load, while the longitudinal and transverse unit strains were measured using strain gauges connected with a measuring amplifier Mikrotechna 1101 and two digital voltmeters.

Assuming that layers (laminae) of the OSB panel are homogenous orthotropic materials, then five elastic constants in a plane stress state are needed to establish the Hooke's law relationship between the stress and strain states for each of the layers. Four of them are independent: the Young's moduli in direction 1 and 2,
$E_{1}$ and $E_{2}$; the shear modulus, $G_{12}$ and the major Poisson's ratio, $v_{12}$. The fifth elastic constant, $v_{21}$, is a function of the other constants, and it may be determined from the relation: $v_{21} E_{1}=v_{12} E_{2}$ (Ashton et al., 1969), regarding the symmetry of the stiffness matrix.

Since the assumption that the OSB layers are homogenous orthotropic materials was not evident in this study, it was decided to experimentally determine all the five elastic constants of each layer in three separate tension tests (Fig. 1). Figure 1 shows three types of tensile specimens cut out from the outer (face) layer of the OSB/3 panel.

The scheme of the tension tests on the inner (core) layer specimens was similar, but on account of different strand orientation in this core layer, which is perpendicular to the major OSB panel axis, $x_{1}$, it was no more the major axis of the orthotropic core layer - it was truly their minor axis.

Finally, destructive tension tests on another 30 specimens (15 face and 15 core specimens), with five specimens of each orientation type $\left(0^{\circ}, 45^{\circ}\right.$ and $90^{\circ}$ with respect to the major OSB panel axis, $x_{1}$ ), were carried out using a FPZ 100/1 testing machine. The crosshead speed of $1.2 \mathrm{~mm} / \mathrm{min}$ was selected so that the failure of the specimen occurred within $90 \pm 30$ seconds. Additionally, the density of the face and core layers was determined, on 25 specimens each time.

\section{RESULTS AND DISCUSSION}

\section{REZULTATI I RASPRAVA}

Two elastic constants: the Young's modulus, $E_{1}$, and the major Poisson's ratio, $v_{12}$, of the face layer (Fig. 1a) and another two: the Young's modulus, $E_{2}$, and the minor Poisson's ratio, $v_{21}$, (Fig. 1b) were calculated as follows: 
Table 1 Elastic constants of the face layer of OSB/3

Tablica 1. Konstante elastičnosti vanjskog sloja OSB/3 ploča

\begin{tabular}{|l|c|c|c|c|c|c|}
\hline \multicolumn{2}{|l|}{$\begin{array}{l}\text { Elastic constant } \\
\text { Konstanta elastičnosti }\end{array}$} & $\begin{array}{c}\text { Mean } \\
\text { Srednja } \\
\text { vrijednost }\end{array}$ & $\begin{array}{c}\text { Std. Dev. } \\
\text { Stand. dev. }\end{array}$ & $\begin{array}{l}\text { Coef. Var. } \\
\text { Koef. var. }\end{array}$ & $\begin{array}{c}\text { Specimens moisture } \\
\text { content, \% } \\
\text { Sadržaj vode u uzorku, \% }\end{array}$ & $\begin{array}{c}\text { Air temperature, }{ }^{\circ} \mathbf{C} \\
\text { Temperatura zraka, }{ }^{\circ} \mathrm{C}\end{array}$ \\
\hline $\begin{array}{l}\text { Young's moduli } \\
\text { Youngov modul, } \\
\text { MPa }\end{array}$ & $E_{1}$ & 5148 & 976 & 19.0 & 6.9 & 24 \\
\cline { 2 - 8 } & $E_{2}$ & 3721 & 628 & 16.9 & 6.9 & 25 \\
\cline { 2 - 8 } $\begin{array}{l}\text { Poisson's ratios } \\
\text { Poissonov omjer }\end{array}$ & $E_{1}$, & 4845 & 1615 & 33.3 & 6.9 & 25 \\
\hline$v_{12}$ & 0.204 & 0.122 & 59.8 & 6.9 & 25 \\
\hline $\begin{array}{l}\text { Shear modulus } \\
\text { modul smicanja } \\
\text { MPa }\end{array}$ & $v_{12}$, & 0.234 & 0.156 & 66.6 & 6.9 & 25 \\
\hline
\end{tabular}

$$
\begin{array}{ll}
E_{1}=\frac{\sigma_{1}}{\varepsilon_{1}} & v_{12}=-\frac{\varepsilon_{2}}{\varepsilon_{1}} \\
E_{2}=\frac{\sigma_{2}}{\varepsilon_{2}} & v_{21}=-\frac{\varepsilon_{1}}{\varepsilon_{2}}
\end{array}
$$

while the shear modulus, $G_{12}$, was obtained in three ways:

directly, from the third tension test (Fig. 1c) as:

$$
G_{12}=\frac{E_{1^{\prime}}}{2 \cdot\left(1+v_{1^{\prime} 2^{\prime}}\right)}
$$

$$
\text { Where: } E_{1^{\prime}}=\frac{\sigma_{1^{\prime}}}{\varepsilon_{1^{\prime}}} \quad v_{1^{\prime} 2^{\prime}}=-\frac{\varepsilon_{2^{\prime}}}{\varepsilon_{1^{\prime}}}
$$

and more indirectly - from all three tension tests (Fig. 1) as:

$$
G_{12}=\frac{\sin ^{2} \alpha \cdot \cos ^{2} \alpha}{\frac{1}{E_{1^{\prime}}}-\frac{\cos ^{4} \alpha}{E_{1}}-\frac{\sin ^{4} \alpha}{E_{2}}+\frac{2 v_{12}}{E_{1}} \cdot \sin ^{2} \alpha \cdot \cos ^{2} \alpha}
$$

and

$$
G_{12}=\frac{\sin ^{2} \alpha \cdot \cos ^{2} \alpha}{\frac{1}{E_{1}}-\frac{\cos ^{4} \alpha}{E_{1}}-\frac{\sin ^{4} \alpha}{E_{2}}+\frac{2 \nu_{21}}{E_{2}} \cdot \sin ^{2} \alpha \cdot \cos ^{2} \alpha}
$$

Where:

$\sigma_{2}, \sigma_{2}, \sigma_{1}, \quad-$ normal stresses

$\varepsilon_{1}, \varepsilon_{2}, \varepsilon_{1}, \varepsilon_{2},-$ longitudinal and transverse unit strains

$E_{1}, E_{2}, E_{1}, \quad-$ moduli of elasticity in the principal ( $x_{1}$ and $x_{2}$ ) OSB panel directions and at $a=45^{\circ}$ with respect to the major OSB panel axis, $x_{1}$, respectively

$v_{12}, v_{21}, v_{1{ }^{\prime} 2}$, Poisson's ratios in principal $\left(x_{1}, x_{2}\right)$ and rotated at $a=45^{\circ}\left(x_{1}, x_{2},\right)$ axes, respectively

Obviously, the formulae (3-5) are valid only in the case when the material tested is orthotropic, in the strict sense (Ashkenazi, 1978).

The results obtained from the elastic tension tests are summarized in Tables 1 and 2. Table 1 presents the results of the tension tests on elastic constants of the outer (face) layer of the $18 \mathrm{~mm}$ thick OSB/3 panel, while Table 2 gives the results of similar tension tests for the inner (core) layer of this panel.

Table 1 clearly shows that the mean value of the Young's modulus of the OSB face layer in the major panel direction, $E_{1}$, is by above $38 \%$ greater than $E_{2}$ (in

\begin{tabular}{|c|c|c|c|c|c|c|}
\hline \multicolumn{2}{|l|}{$\begin{array}{l}\text { Elastic constant } \\
\text { Konstanta elastičnosti }\end{array}$} & $\begin{array}{c}\text { Mean } \\
\text { Srednja } \\
\text { vrijednost }\end{array}$ & $\begin{array}{l}\text { Std. Dev. } \\
\text { Stand. dev. }\end{array}$ & $\begin{array}{l}\text { Coef. Var. } \\
\text { Koef. var. }\end{array}$ & $\begin{array}{c}\text { Specimens moisture } \\
\text { content, \% } \\
\text { Sadržaj vode u uzorku, \% }\end{array}$ & $\begin{array}{l}\text { Air temperature, }{ }^{\circ} \mathrm{C} \\
\text { Temperatura zraka, }{ }^{\circ} \mathrm{C}\end{array}$ \\
\hline \multirow{3}{*}{$\begin{array}{l}\text { Young's moduli, } \mathrm{MPa} \\
\text { Youngov modul, } \mathrm{MPa}\end{array}$} & $E_{1}$ & 1666 & 285 & 17.1 & 8.5 & 25 \\
\hline & $E_{2}$ & 2314 & 533 & 23.0 & 8.5 & 25 \\
\hline & $E_{1}$, & 2221 & 785 & 35.3 & 8.5 & 25 \\
\hline \multirow{3}{*}{$\begin{array}{l}\text { Poisson's ratios } \\
\text { Poissonov omjer }\end{array}$} & $v_{12}$ & 0.202 & 0.145 & 71.8 & 8.5 & 25 \\
\hline & $v_{21}$ & 0.226 & 0.080 & 35.4 & 8.5 & 25 \\
\hline & $v_{1,2}$, & 0.239 & 0.080 & 33.5 & 8.5 & 25 \\
\hline \multirow{3}{*}{$\begin{array}{l}\text { Shear modulus, } \mathrm{MPa} \\
\text { modul smicanja, } \mathrm{MPa}\end{array}$} & \multirow{3}{*}{$G_{12}$} & 896 & \multicolumn{4}{|c|}{ Calculated by the formula (3) / izračunano prema jednadžbi (3) } \\
\hline & & 989 & \multicolumn{4}{|c|}{ Calculated by the formula (4) / izračunano prema jednadžbi (4) } \\
\hline & & 1037 & \multicolumn{4}{|c|}{ Calculated by the formula (5) / izračunano prema jednadžbi (5) } \\
\hline
\end{tabular}
the minor panel direction). The mean value of $E_{1}$, Young's modulus in the $x_{1}$, direction (Fig. 1c) turned out to be smaller than $E_{1}$ but greater by $30 \%$ than $E_{2}$.

Table 2 Elastic constants of the core* layer of OSB/3

Tablica 2. Konstante elastičnosti za unutarnji sloj OSB/3 ploča

* The major OSB panel axis, $x_{1}$, is not the major axis of the core layer but it is their minor axis. / Glavna os OSB ploče $x_{1}$ nije glavna os unutarnjeg sloja ploče, ali je njegova druga os. 
From amongst the Young's moduli determined for the OSB face layer, the $E_{1}$, modulus produces the most scattered results.

The determination of the Poisson's ratios for OSB is significantly more difficult than the determination of the Young's moduli (Thomas, 2003) because it requires very sensitive measuring equipment and, additionally, is considerably affected by the OSB heterogeneous structure. The "major" Poisson's ratio, $v_{12}$, produces the most scattered results, and the Poisson's ratio, $v_{1,2}$, the least scattered results, as determined during the tension test on diagonal specimens (Fig. 1c). The value of $v_{1,2}$, turned out to be much greater (by above $78 \%$ ) than $v_{12}$ and by above $55 \%$ greater than $v_{21}$ (Table 1). The mean value of the shear modulus, $G_{12}$, of the face layer depending on the formula (3, 4 or 5) used, ranged from $1776 \mathrm{MPa}$ to $2263 \mathrm{MPa}$.

Table 2 clearly shows that the mean value of the Young's modulus of the OSB core layer in the minor panel direction, $E_{2}$, is by above $39 \%$ greater than $E_{1}$ (in the major panel direction). The mean value of $E_{1}$, Young's modulus (in the $x_{1}$, direction) turned out to be somewhat smaller than $E_{2}$ but by $33 \%$ greater than $E_{1}$. Among the Young's moduli determined for the core OSB layer, this $E_{1}$, modulus, like that for the face layer, produces the most scattered results. Table 2 clearly shows that the mean value of the shear modulus, $G_{12}$, of the core layer ranged from $989 \mathrm{MPa}$ to $1037 \mathrm{MPa}$, depending on the formula $(3,4$ or 5$)$ used. Comparing the Young's moduli values of both the OSB panel layers (Tables 1 and 2), it is evident (taking into account the same strand orientation to the applied tension in testing) that the Young's moduli of the face layer are 2.18 -2.23 times higher than those of the core layer.

The ratios of the $E_{1}$ (face) to the $E_{2}$ (core) and of the $E_{2}$ (face) to the $E_{1}$ (core) were practically identical and amounted to 2.22 and 2.23, respectively. Only the ratio of the $E_{1}$ (face) to $E_{1}$, (core) was slightly lower and amounted to 2.18 .

Similar relationship can be observed between the shear moduli values of both the OSB panel layers. The ratio of the $G_{12}$ (face) to the $G_{12}$ (core) amounted to 1.98 (taking into account values obtained from the formulae 3 or 5) and 2.29 (taking into account the formula 4). All the obtained Young's and shear moduli were, therefore, twice or more higher in the face layer than in the core layer.

This phenomenon was probably caused by greater density of the face layer than that of the core layer. The density measurements of OSB layers (each time on 25 samples) resulted in mean densities (taking into account the standard deviation) of $749 \pm 22 \mathrm{~kg} / \mathrm{m}^{3}$ for the face layer and $535 \pm 12 \mathrm{~kg} / \mathrm{m}^{3}$ for the core layer. Therefore, it turned out that the face layer density was 1.4 times greater than the core layer density. This face/ core density ratio is in good accordance with the results of the numerical simulations of OSB vertical density profile carried out by Painter et al. $\left(2006^{\mathrm{a}}\right)$. Taking into consideration earlier obtained OSB panel density of $593 \mathrm{~kg} / \mathrm{m}^{3}$, it was possible to estimate the thickness of each layer. These estimated values of $0.7 h$ for the core layer (where $h$ - thickness of the OSB panel) and 0.15 $h$ for the face layer are in good accordance with the data obtained on the basis of our own earlier, unpublished experiments.

Similar correlation between Young's moduli in tension and density of OSB layers was proved by Steidl et al. (2003). They explained the relatively high scatter of tensile properties of OSB layer (average coefficient of variation of $39 \%$ ) by the small specimen size used in their work. In this study, in spite of the smaller specimen size, the average coefficient of variation for all Young's moduli of both the OSB layers was considerably lower and amounted to $19 \%$. It was probably caused by the greater thickness of the face and core specimens ( 3 and $5.5 \mathrm{~mm}$, respectively) than in the experiment of Steidl et al. (2003), where it was about 1.2 mm. The smaller thickness of the OSB specimens undoubtedly resulted in their higher non-homogeneity.

Specimens cut from an entire OSB panel parallel to their major axis, $x_{1}$, will indicate greater differentiation of elastic properties through the thickness than specimens cut perpendicular to this axis. The ratio of the $E_{1}$ (face) to the $E_{1}$ (core) amounted to 3.09 , while the ratio of the $E_{2}$ (face) to the $E_{2}$ (core) only amounted to 1.61. This will be due to a combination of a denser face and the strands being oriented parallel or perpendicular to the applied tension. Steidl et al. (2003) came to similar conclusions.

The values of Poisson's ratios (except $v_{1,2}$,) turned out to be quite similar for both the layers. Similarly as for the face layer, $v_{1,2}$, achieved the highest value of the Poisson's ratio for the core layer - obtained at $45^{\circ}$ to the principal $\left(x_{1}\right.$ and $\left.x_{2}\right)$ OSB panel directions.

In spite of identical test conditions (air temperature and relative humidity), the moisture content (MC) of face and core specimens, determined after the elastic tension testes were completed (Tables 1 and 2), turned out not to be identical. The $\mathrm{MC}$ of the core specimens $(8.5 \%)$ was somewhat higher than that of the face specimens $(6.9 \%)$. This phenomenon was probably caused by the lower density of the core layer and by some OSB processing factors, too. Neimsuwan et al., (2008) established that a higher compression ratio leads to a slight decrease in strands equilibrium moisture content (EMC). They additionally stated that the strand EMC is affected by the platen temperature as well as by the wax and resin loading.

Table 3 summarises the results of the additional, destructive tension tests on the OSB face and core layers. It shows that the samples cut from the OSB face layer at $0^{\circ}$ (to the major OSB axis, $x_{1}$ ) had the highest tensile strength, while the samples cut from the core layer at the same direction had the lowest tensile strength. The values of the mean tensile strength for all types of core samples $\left(0^{\circ}, 45^{\circ}\right.$ and $\left.90^{\circ}\right)$ turned out to be decidedly lower than those obtained for the face samples. All the tensile strength data in Table 3 are surprisingly low in comparison with the PN EN 12369-1 (2002) standard requirements for the OSB/3 (9.4 MPa at $0^{\circ}$ and $7 \mathrm{MPa}$ at $90^{\circ}$, respectively). This phenomenon was probably caused by the modified experiment 
Table 3 Tensile strength of the layers of OSB/3

Tablica 3. Vlačna čvrstoća slojeva OSB/3 ploča

\begin{tabular}{|c|c|c|c|c|c|c|}
\hline \multirow{2}{*}{$\begin{array}{l}\text { Layer } \\
\text { Sloj }\end{array}$} & \multirow{2}{*}{$\begin{array}{l}\text { Angle to } x_{1} \text { axis } \\
\text { (sample type) } \\
\text { Kut u odnosu } \\
\text { prema osi } x_{1}\end{array}$} & \multirow{2}{*}{$\begin{array}{c}\text { Mean cross-section } \\
\text { Srednji poprečni } \\
\text { presjek } \\
\mathrm{mm}^{2}\end{array}$} & \multirow{2}{*}{$\begin{array}{c}\text { Mean } \\
\text { destructive force } \\
\text { Srednja sila loma } \\
\mathrm{N}\end{array}$} & \multicolumn{3}{|c|}{$\begin{array}{l}\text { Tensile strength, } \mathrm{MPa} \\
\text { Vlačna čvrstoća, } M P a\end{array}$} \\
\hline & & & & $\begin{array}{l}\text { Mean } \\
\text { Srednji }\end{array}$ & $\begin{array}{l}\text { Std. Dev. } \\
\text { Stand. dev. }\end{array}$ & $\begin{array}{l}\text { Coef. Var. } \\
\text { Koef. var. }\end{array}$ \\
\hline \multirow{3}{*}{$\begin{array}{l}\text { upper } \\
\text { face } \\
\text { vanjski sloj }\end{array}$} & $0^{\circ}$ & 85.26 & 950 & 11.15 & 1.74 & 15.6 \\
\hline & $45^{\circ}$ & 86.60 & 506 & 5.84 & 0.75 & 12.8 \\
\hline & $90^{\circ}$ & 91.06 & 561 & 6.15 & 0.76 & 12.3 \\
\hline \multirow{3}{*}{$\begin{array}{l}\text { core* } \\
\text { unutarnji sloj }\end{array}$} & $0^{\circ}$ & 167.34 & 642 & 3.84 & 0.20 & 5.2 \\
\hline & $45^{\circ}$ & 168.86 & 737 & 4.37 & 0.46 & 10.4 \\
\hline & $90^{\circ}$ & 167.36 & 766 & 4.58 & 0.54 & 11.8 \\
\hline
\end{tabular}

* The major OSB panel axis, $x_{1}$, is not the major axis of the core layer but it is their minor axis. / Glavna os OSB ploče $x_{1}$ nije glavna os unutarnjeg sloja ploče, ali je njegova druga os.

procedure due to the use of very thin samples. Because of that, the increased non-homogeneity of these samples, in regard to the whole OSB panel, has probably increased the stress concentration and induced their premature failure.

Specimens cut from an entire OSB panel parallel to their major axis, $x_{1}$, will be indicate greater differentiation of strength properties through the thickness than specimens cut perpendicular to this axis.

In the first case, the ratio of the tension strength of the face to the core layer amounted to 2.9, while in the second case it was only 1.34 . This was, similarly as for elastic properties, due to a combination of a denser face and the strands being oriented parallel or perpendicular to the applied tension. The first ratio is smaller and the second greater than those reported by Steidl et al. (2003).

\section{CONCLUSIONS}

4. ZAKLJUČAK

All the obtained results confirmed that the face and core layers of commercial OSB/3 panel, $18 \mathrm{~mm}$ thick, differ considerably with respect to density, elastic and strength properties. However, they show the characteristics of an orthotropic material with their strongest properties in the direction of the strand orientation. Due to the lack of the manufacturer's data on the thickness of individual layers of OSB panel, the thickness of each face layer was, experimentally, estimated between 2 and $3.5 \mathrm{~mm}$. The density of the face layer was $40 \%$ higher in comparison with that of the core layer. According to all three investigated directions $\left(0^{\circ}, 45^{\circ}\right.$ and $\left.90^{\circ}\right)$ used in this study, all the Young's moduli of the face layer were 2.18 - 2.23 times higher than those of the core layer. Similarly, the shear modulus of the face layer was twice higher than that of the core layer. Only the values of Poisson's ratios (except for $v_{1,2}$ ) were quite similar for both layers. In spite of the distinct differences between the values of all the elastic moduli obtained for both OSB/3 layers, the ratios of the $E_{1}$ to $E_{2}$ moduli for each layer were practically identical and amounted to 1.38 (in the core layer $E_{2}$ to $E_{1}$ ). This phenomenon is probably caused by a similar degree of strand alignment in both face and core layers. The tensile strength values for both OSB layers showed distinct differences, too. The ratios of the tension strength of face to core layer obtained in tension tests at $0^{\circ}, 45^{\circ}$ and $90^{\circ}$ (with respect to the strand direction) were 2.43, 1.34 and 1.6, respectively.

Specimens cut from the entire OSB panel parallel to their major axis will indicate greater differentiation of elastic and strength properties through the thickness than specimens cut perpendicular to this axis. This phenomenon is caused by a combination of denser OSB face and identity of strands and tension directions.

This study enhances the understanding of the mechanical behaviour of OSB panels and may be useful to predict OSB panel bending, elastic and strength properties.

\section{REFERENCES}

5. LITERATURA

1. Ashkenazi, E. K., 1978: Anizotropia drewesiny i drewesnykh materialow (in Russian). Moskwa: Lesnaya Promyshlennost.

2. Ashton, J. E.; Halpin, J. C.; Petit, P. H., 1969: Primer on composite materials: Analysis. Stamford, Conn.: Technomic Publishing.

3. Bodig, J.; Jayne, B. A., 1982: Mechanics of wood and wood composites. New York, Cincinnati, Toronto, London, Melbourne: Van Nostrand Reinhold Company Inc.

4. Böhm, M.; Šedivka, P.; Bomba, J.; Reisner, J., 2011: Strength Characteristics of OSB in bending - difference between upper and lower panel faces. Drvna industrija, 62 (2): 123-127.

http://dx.doi.org/10.5552/drind.2011.1036

5. Canadido, L. S.; Saito, F.; Suzuki, S., 1988: Effect of particle shape on the orthotropic properties of oriented strand board. Mokuzai Gakkaishi, 34 (1): 21-27.

6. Carll, C. G.; Link, C. L., 1988: Tensile and compressive MOE of flakeboards. Forest Products Journal, 38 (1): 8-14.

7. Chen, S.; Fang, L.; Lin, X.; Wellwood, R., 2008: Effect of mat structure on modulus of elasticity of oriented strandboard. wood Sci. Technol., 42: 197-210. http://dx.doi.org/10.1007/s00226-007-0167-0.

8. Neimsuwan, T.; Wang, S.; Via, B. K., 2008: Effect of processing parameters, resin, and wax loading on water vapor sorption of wood strands. Wood and Fiber Science, 40 (4): 495-504.

9. Nishimura, T.; Amin, J.; Ansell, M. P., 2004: Image analysis and bending properties of model OSB panels as a function of strand distribution, shape and size. Wood Science and Technology, 38: 297-309. http://dx.doi.org/10.1007/s00226-003-0219-z. 
10. Painter, G.; Budman, H.; Pritzker, M., 2006a: Prediction of oriented strand board properties from mat formation and compression operating conditions. Part 1 . Horizontal density distribution and vertical density profile. Wood Science and Technology, 40: 139-158. http://dx.doi.org/10.1007/s00226-005-0044-7.

11. Painter, G.; Budman, H.; Pritzker, M., 2006b: Prediction of oriented strand board properties from mat formation and compression operating conditions. Part 2. MOE prediction and process optimization. Wood Science and Technology, 40: 291-307. http://dx.doi.org/10.1007/s00226-005-0050-9.

12. Shupe, T. F.; Hse, C. Y.; Price, E. W., 2001: Flake orientation effects on physical and mechanical properties of sweetgum flakeboard. Forest Products Journal, 51 (9): 38-43.

13. Steidl, C. M.; Wang, S.; Bennett, R. M.; Winistorfer, P. M., 2003: Tensile and compression properties through the thickness of oriented strandboard. Forest Products Journal, 53 (6): 72-80.

14. Suzuki, S., 2000: Effects of strand length and orientation of strength properties of OSB made from Japanese cedar. In: Proceedings of the world conference of timber engineering, Whistler Resort, British Columbia, Canada, July 31-August 3, 2000, 1.3.8.1-1.3.8.8.

15. Thomas, W. H., 2003: Poisson's ratios of an oriented strand board. Wood Science and Technology, 37: 259268. http://dx.doi.org/10.1007/s00226-003-0171-y.

16. Wang, S.; Winistorfer, P. M., 2000: Fundamentals of vertical density profile formation in wood composites. Part II. Methodology of vertical density formation under dynamic conditions. Wood and Fiber Science, 32 (2): 220-238.

17. Wang, S.-Y.; Chen, B.-J., 2001: The flake's alignment efficiency and orthotropic properties of oriented strand board. Holzforschung, 55 (1): 97-103. https://doi. org/10.1515/HF.2001.016.

18. Winistorfer, P. M.; Moschler, W. W.; Wang, S.; DePaula, E.; Bledsoe, B. L., 2000: Fundamentals of vertical density profile formation in wood composites. Part I. In-situ density measurement of the consolidation process. Wood and Fiber Science, 32 (2): 209-219.
19. Xu, W., 2000: Influence of percent alignment and shelling ratio on modulus of elasticity of oriented strandboard: A model investigation. Forest Products Journal, 50 (10): 43-47.

20. Zhu, E. C.; Guan, Z. W.; Rodd, P. D.; Pope, D. J., 2005: A constitutive model for OSB and its application in finite element analysis. Holz als Roh-und Werkstoff, 63: 87-93. http://dx.doi.org/10.1007/s00107-004-0513-y.

21. *** PN-EN 12369-1 (2002): Wood-based panels - Characteristic values for structural design - Part 1: OSB, particleboards and fibreboards.

22. *** PN-EN 300 (2007): Oriented Strand Boards (OSB) - Definitions, classification and specifications.

23. *** PN-EN 310 (1994): Wood-based panels - Determination of modulus of elasticity in bending and of bending strength.

24. *** PN-EN 322 (1999): Wood-based panels - Determination of moisture content.

25. *** PN-EN 323 (1999): Wood-based panels - Determination of density.

26. *** PN-EN 789 (1998): Timber structures - Tests methods - Determination of mechanical properties of wood based panels.

\section{Corresponding address:}

Assoc. Prof. RYSZARD PLENZLER, Ph. D.

Poznań University of Life Sciences

Faculty of Wood Technology

Department of Engineering Mechanics and Thermal Techniques

ul. Wojska Polskiego 38/42

60-627 Poznań, POLAND

e-mail: rplenzle@up.poznan.pl 